
\title{
BENUA EROPA DAN SISTEM HUKUM NASIONAL INDONESIA
}

Jurnal Penegakan Hukum Indonesia (JPHI)

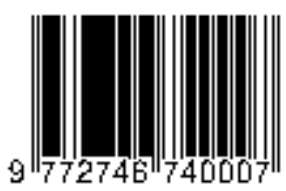

JPHI E-ISSN 2746-7406

JPHI P-ISSN 2808-4896

\author{
R. Alexander J. Syauta \\ Magister Ilmu Hukum \\ Program Pascasarjana, Universitas Balikpapan \\ JIn. Pupuk Raya Gunung Bahagia, Kota Balikpapan, \\ Provinsi Kalimantan Timur, \\ Indonesia \\ Email : joe.syauta@gmail.com
}

\begin{abstract}
Submitted : 07/02/2022
Revised : :10/02/2022

Accepted : 11/02/2022

Published : 11/02/2022

Editorial Office:

Jl. Brigjen H. Hasan Basri Komplek Polsek Banjarmasin Utara Jalur 3, No. 9 Kota Banjarmasin; Provinsi Kalimantan Selatan; Republik Indonesia (70125).
\end{abstract}

\section{Email}

jphi.scholarcenter@gmail.com

Principal Contact

+62 81256812202

(C) 2021 by the authors. Submitted for open access publication in Jurnal Penegakan Hukum Indonesia (JPHI) under the terms and conditions of the Creative Commons AttributionNonCommercial-ShareAlike $\quad 4.0$ license (CC BY NC SA 4.0). For more information visit (http://creativecommons.org).

\section{Abstract}

The state needs every adjustment between what is really needed by the state to be able to regulate the actions and actions of its citizens without the foundation and foundation that is the main basis for the creation of policies and/or a rule that is applied as a whole as a legal system. . Historically, seen from the History and Politics of Law, Sources of Law and the Law Enforcement System, the legal system in Indonesia adheres to the Continental European legal system or Civil Law. The legal system is a legal system adopted by most European countries such as the Netherlands, France, Italy and Germany. However, as the times progressed, the boundaries between Public Law and Private Law became increasingly blurred. In its formation, the prevailing laws and regulations in Indonesia were influenced by the Customary Law System and the Islamic Law System. The modification of the applied legal system raises the question, What is the current legal system applied in the territory of the Unitary State of the Republic of Indonesia ("NKRI")? Is it true that it is the result of the absorption of the European Continental Legal System which is then adapted to the needs of the State? And is the current legal system in the territory of the Republic of Indonesia the right legal system that can be a means of protection, the right tool and the orderliness of society as well as a means of realizing social justice? This will be discussed more in writing with the type of Legal Historical Research where in its completion it uses Normative or Literary Research Methods and uses Normative Juridical Techniques which is carried out through the Study and Collection of Primary, Secondary, and Tertiary library materials for reference and broadening of horizons to find out and draw related to the Comparison of the European Legal System and the Indonesian Legal System, as well as how it is implemented nationally in the territory of the Republic of Indonesia.

Keywords : Legal System; European Continent; Indonesia 


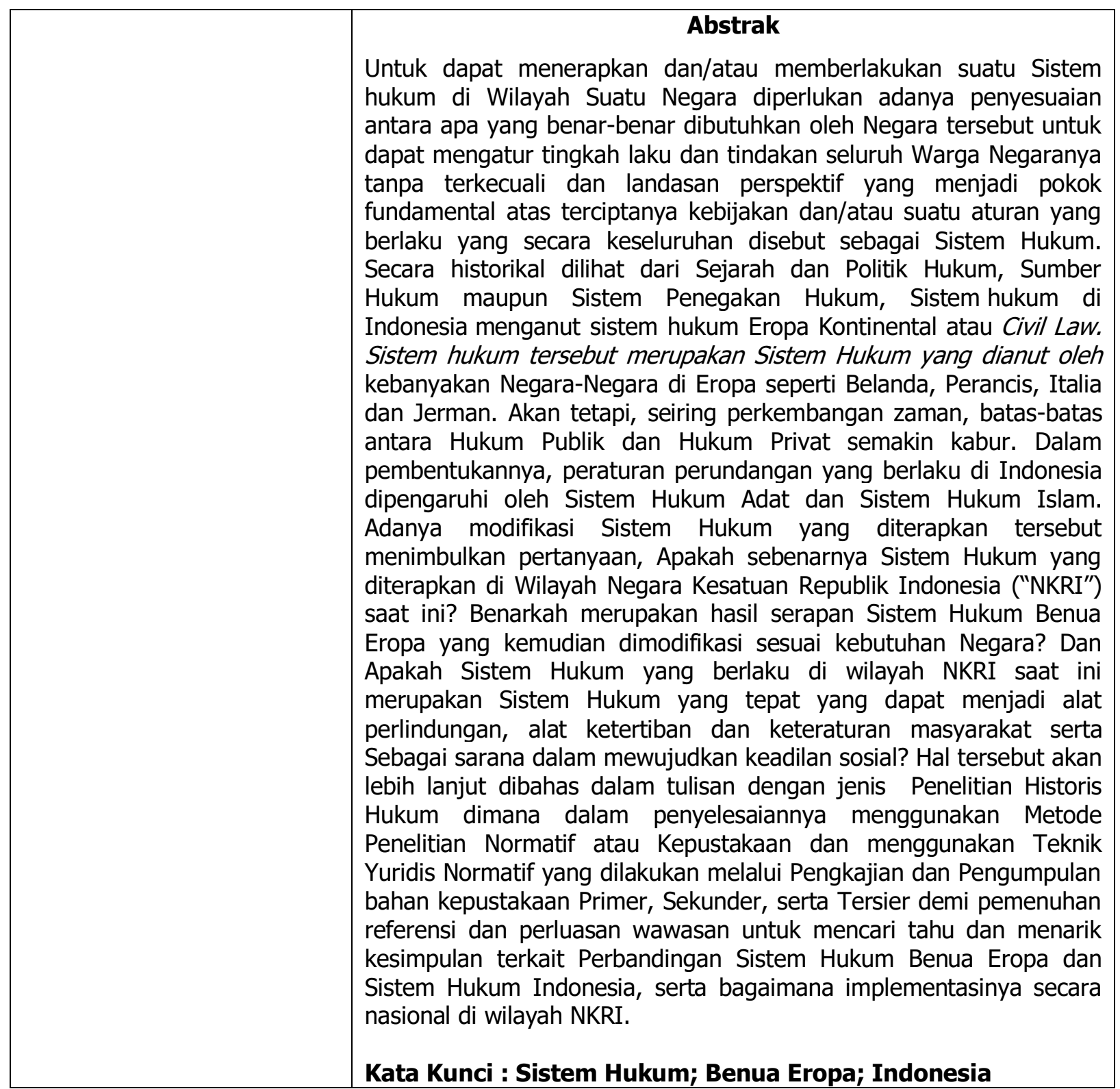

\section{PENDAHULUAN}

Secara definisi perbandingan hukum dapat dikatakan sebagai upaya untuk mempelajari hukum dengan melakukan perbandingan, baik persamaan maupun perbedaan hukum yang belaku. ${ }^{1}$ Secara studi atau akademis, perbandingan tentang hukum tidak dapat dipisahkan dengan dengan studi ilmu hukum sendiri, sehingga bisa dikatakan studi perbandingan hukum setua ilmu hukum. Upaya untuk melakukan perbandingan hukum bertitik tolak pada pandangan bahwa bangsa -

\footnotetext{
${ }^{1}$ Irwansyah, Kajian IImu Hukum (Yogyakarta: Mirra Buana Media, 2020). hlm. 250
} 
bangsa di dunia memiliki tata hukum masing - masing. ${ }^{2}$

Studi perbandingan hukum mulai berkembang pada abad ke - 19 sebagai cabang ilmu khusus dari studi ilmu hukum dan jika ditilik berdasarkan obyeknya, kajian dapat dilakukan pada : ${ }^{3}$

1. Sistem hukum;

2. Konsepsi hukum;

3. Sumber hukumnya;

4. Sebab - sebab atau latar belakang sosial budaya berbagai negara ;

5. Perbandingan hukum antara bidang hukum tertentu, dan sebagainya.

Sistem hukum adalah kesatuan utuh dari tatanan-tatanan yang terdiri atas bagian atau unsur yang satu sama lain saling berhubungan dan berkaitan secara erat di mana untuk mencapai suatu tujuan, kesatuan tersebut diperlukan kerja sama, rencana, dan pola tertentu. ${ }^{4}$ Sistem hukum sendiri merupakan sistem yang abstrak dan terbuka, serta memiliki ciri ciri yang dapat dikenali: ${ }^{5}$

1. Sistem hukum bersifat continue, berkesinambungan, dan otonomi.

2. Sistem hukum mempunyai sifat konsisten atau ajek menghadapi konflik.

3. Sistem hukum tidak menghendaki adanya konflik antar unsur - unsur atau bagian - bagian.

4. Sistem hukum bersifat lengkap.

5. Sistem hukum mempunyai konsep fundamental.

Pelopor - pelopor perbandingan sistem hukum ini, antara lain :

1. Montesquieu

2. Mansfield

3. Von Feuerbach, dan lain - lain

Perbandingan sistem hukum sendiri memiliki manfaat :

1. Membawa sikap kritis terhadap sistem hukum sendiri.

2. Membawa sikap yang tepat dalam kaitannya dengan hukum negara lain.

3. Harmonisasi hukum antar negara.

\footnotetext{
${ }^{2}$ Muhammad Hadyan Yunhas Purba, Hasim., \& Purba, Dasar-Dasar Pengetahuan IImu Hukum (Jakarta: Sinar Grafika). HIm 103

${ }^{3}$ Irwansyah. Op.Cit.

${ }^{4}$ Purba, Hasim., \& Purba. Op.Cit. HIm 174

${ }^{5}$ Satjipto Rahardjo, IImu Hukum (Bandung: Citra Aditya Bakti, 2006).HIm 26
} 
Saat ini di dunia ada beberapa sistem hukum yang berlaku :

1. Sistem Common Law / Anglo Saxon

2. Sistem Civil Law / Continental Europe

3. Sistem Hukum Adat / Lokal

4. Sistem Hukum Islam / Agama

5. Sistem Hukum Komunis / Sosialis

6. Sistem Hukum Campuran

Sistem hukum - sistem hukum ini berkembang bersamaan dengan perkembangan wilayah baik melalui kolonisasi, penjajahan, maupun perdagangan antar negara, sebagai contohnya Common Law yang berasal dari Inggris, berkembang bersama dengan kolonisasi atau persemakmuran Inggris. Selain itu terdapat Civil Law yang berkembang melalui perdagangan ketika VOC datang ke Indonesia dan kemudian berkembang ketika Belanda menjajah Indonesia.

Bersamaan dengan sejarah dan waktu, timbulah suatu Sistem Hukum Campuran, sistem hukum ini merupakan hybrid atau campuran dari berbagai sistem hukum. Sistem ini seringkali terjadi di negara - negara yang awalnya memiliki kecondongan pada suatu sistem tertentu namun merasa perlu memasukkan unsur unsur lama dan / atau baru sebagai akibat dari evolusi sebagai bangsa dan negara, sekaligus mempertahankan identitas kebangsaan.

Saat ini pola sistem hukum ini juga yang akhirnya diterapkan di Indonesia, walaupun secara keseluruhan Indonesia memiliki kecenderungan pada suatu sistem hukum tertentu. Hal ini karena evolusi hukum dan sosial di Indonesia merasa perlu mengikuti perkembangan teknologi dan keinginan masyarakat.

Jadi melihat kepada diskusi di atas, penyebab pertumbuhan sistem hukum di dunia dapat dikerucutkan pada politik, ekonomi, kebudayaan, dan saat ini satu hal lagi yang bisa menjadi factor perubahan terhadap pertumbuhan sistem hukum, yaitu teknologi. Teknologi cukup berperan salam suatu sistem hukum sehingga suatu sistem hukum bisa jadi mengalami perkembangan demi memfasilitasi perkembangan teknologi, sebagai contoh timbulnya Undang - Undang Informasi Transaksi Elektronik.

Pembahasan lebih lanjut berkaitan dengan Common Law, Civil Law, dan Sistem Hukum Indonesia dapat ditemukan pada bab - bab selanjutnya. 


\section{RUMUSAN MASALAH}

Adapun rumusan masalah dalam penelitian ini adalah :

1. Apa perbandingan antara Sistem Hukum Benua Eropa dan Sistem Hukum Indonesia?

2. Bagaimana Penerapan Sistem Hukum secara nasional di Indonesia yang merupakan hasil serapan dari Sistem Hukum yang berlaku di Benua Eropa?

\section{METODE PENELITIAN}

Jenis penelitian dalam penulisan ini yakni ialah Penelitian Historis Hukum dimana dalam penyelesaiannya menggunakan Metode Penelitian Normatif atau Kepustakaan yang kemudian digunakan sebagai dasar teknis untuk mendapatkan data-data yang relevan mengenai sejarah dan perbandingan Sistem Hukum Benua Eropa dan Sistem Hukum Indonesia, dan bagaimana penerapannya di masingmasing Wilayah tersebut serta penelusuran lebih dalam terkait apakah masingmasing Sistem Hukum tersebut dalam penerapannya saling mempengaruhi dan/atau dipengaruhi mengingat adanya sejarah penjajahahan oleh Warga Negara Benua Eropa di Wilayah Negara Indonesia Negara sebelum masa kemerdekaannya sehingga masih meninggalkan dasar-dasar aturan hingga Sistem Hukum yang kemudian diserap dan/atau dipertahankan hingga saat ini di Wilayah Negara Kesatuan Republik Indonesia (NKRI). Tehnik analisis dilakukan secara deskriptif dan eksplanatoris dengan tujuan untuk mengetahui apakah benar bahwasanya Sistem Hukum Indonesia merupakan serapan dari Sistem Hukum Benua Eropa dan kemudian Sistem Hukum yang bagaimanakah yang sepatutnya berlaku di Indonesia saat ini yang sesuai dengan kaidah, nilai, norma dan kebutuhan seluruh warga negaranya. Untuk menjawab hal tersebut, Penulis menggunakan Teknik Yuridis Normatif yang dilakukan melalui Pengkajian dan Pengumpulan bahan kepustakaan Primer, Sekunder, serta Tersier demi pemenuhan referensi dan perluasan wawasan untuk mencari tahu dan menarik kesimpulan terkait Perbandingan Sistem Hukum Benua Eropa dan Sistem Hukum Indonesia. 


\section{PEMBAHASAN}

\section{SISTEM HUKUM BENUA EROPA}

Benua Eropa merupakan benua yang sebenarnya cukup kecil dan dapat dibagi menjadi 2 daratan utama. Jika pembagian daratan dilakukan berdasarkan jangkauan kekuasaan dan luas wilayah, mengacu kepada 2 kriteria ini timbullah dikotomi benua Eropa daratan yang terdiri dari negara - negara Eropa daratan seperti Prancis, Jerman, Belanda, Belgia dan lain - lain dan di sisi lain terdapat Inggris.

Secara kekuasaan Inggris memiliki kemampuan yang sangat diperhitungkan, terbukti pada Perang Dunia I dan II Inggris secara mandiri dapat menghadapi gabungan negara negara Eropa daratan, walaupun kemudian memang dalam perjalanan waktunya Inggris membutuhkan aliansi dengan Amerika Serikat. Selain itu, secara ekonomi konteks Brexit atau British Exit dari Uni Eropa juga menjadi perbincangan hangat di kalangan ekonom dunia hari - hari ini. Uni Eropa sebagai informasi merupakan gabungan dari negara negara yang berada pada daratan utama Eropa ditambah dengan Inggris.

Keberanian dan kematangan ekonomi, politik, dan hukum dari Inggris selalu mewarnai dunia, dan itu pula sebabnya Inggris memiliki suatu sistem hukum yang terpisah dari negara negara lain di kawasan Eropa.

\section{SISTEM HUKUM COMMON LAW}

Sistem hukum Common Law merupakan sistem hukum yang berasal dari Inggris dan kemudian berkembang di negara - negara jajahan Inggris dan / atau persemakmuran Inggris, seperti Australia atau Kanada. Sistem ini juga berpengaruh di Amerika mengingat Amerika pada satu titik dalam sejarah merupakan koloni Inggris sebelumnya akhirnya mendapatkan kemerdekaannya.

Sistem ini juga dikenal dengan beberapa nama Sistem Anglo Saxon, Unwritten Law, Case Law, atau sistem hukum kebiasaan. Sistem ini timbul sebagai akibat evolusi hukum, dan dipelopori oleh lembaga lembaga peradilan serta para professional yang ada di baliknya. 
Karakteristik sistem hukum ini mengacu kepada 3 hal : ${ }^{6}$

a) Sumber hukum pada putusan hakim atau putusan pengadilan atau yurisprudensi.

b) Point 1 menghasilkan point 2 yaitu keputusan hakim yang terdahulu menjadi acuan keputusan hakim yang sekarang atau yang biasa disebut sebagai the binding force of precedent. ${ }^{7}$ Doktrin ini disebut juga sebagai stare decisis. ${ }^{8}$ Doktrin ini pula yang menyebabkan hakim memiliki wewenang yang luas untuk memberikan tafsir peraturan hukum dan menciptakan prinsip - prinsip hukum baru yang berguna sebagai pegangan bagi hakim selanjutnya. ${ }^{9}$

c) Adversary system dalam proses peradilan. Adversary system adalah cara penanganan perkara dengan melakukan perundingan atau negosiasi dengan para pihak antara tertuduh dan penuntut umum, merupakan bagian yang tidak terpisahkan dari keseluruhan sistem penegakan hukum yang berlaku, sehingga cara ini merupakan salah satu prosedur formal dan legal. Praktek tersebut dikenal dengan nama "plea bargaining system ". 10

\section{SISTEM HUKUM CIVIL LAW}

Sistem hukum ini merupakan landasan sistem yang digunakan oleh kebanyakan negara negara di Eropa daratan atau yang saat ini lebih dikenal dengan nama Uni Eropa. Sistem ini memiliki latar belakang sampai kepada zaman Romawi kuno namun tentu saja berkembang bersama dengan evolusi waktu sesuai dengan aliran hukum sejarah. Sistem hukum ini berasal dari kodifikasi hukum yang berlaku pada Kekaisaran Romawi, khususnya masa

\footnotetext{
${ }^{6}$ Irwansyah. Op.Cit. HIm 176

${ }^{7}$ Ibid, hlm 63

${ }^{8}$ Ibid, hlm 63

${ }^{9}$ Purba, Hasim., \& Purba. Op.Cit. HIm 176

${ }^{10}$ Sri Rahayu, 'Hak Tertuduh Dalam Peradilan Pidana Berdasarkan Adversary System', Jurnal Inovatif, VIII.I (2015), HIm 32.
} 
pemerintahan Kaisar Yustianus. ${ }^{11}$ Hal ini menjadikan sistem hukum ini sebagai sistem tertua yang ada di dunia. ${ }^{12}$

Apabila prinsip utama pada common law adalah yurisprudensi atau keputusan pengadilan, civil law mengacu kepada undang - undang yang tersusun secara sistematis dalam sebuah kodifikasi yang bertujuan untuk memberikan kepastian hukum. Kodifikasi hukum merupakan kumpulan dari pelbagai kaidah hukum sebelum masa kaisar Yustianus. Kodifikasi ini disebut Corvus Juris Civilis. ${ }^{13}$

Karakteristik sistem hukum ini adalah $:^{14}$

a) Adanya kodifikasi yang terus dikembangkan bersamaan dengan waktu sejak zaman Romawi Kuno.

b) Hakim tidak terikat pada preseden sehingga undang - undang menjadi sumber hukum yang terutama.

c) Sistem peradilan bersifat inkuisitorial. Inkuisitorial maksudnya bahwa dalam sistem ini, hakim mempunyai peranan yang besar dalam mengarahkan dan memutus suatu perkara. ${ }^{15}$

\section{SISTEM HUKUM INDONESIA}

Indonesia sebagai negara kepulauan memiliki latar belakang sejarah yang cukup panjang, dari zaman kerajaan hingga melibatkan penjajahan dari 3 negara yaitu Portugis, Belanda, dan Inggris. Hal ini membuat Indonesia banyak terpengaruh oleh sistem hukum negara - negara Eropa terutama sistem hukum Civil Law mengingat Indonesia berada di bawah penjajahan Belanda yang sifatnya hampir menyeluruh di semua kepulauan Indonesia dengan jangka waktu yang cukup panjang +/- 350 tahun, namun selain itu perlu disorot juga terdapat beberapa sistem hukum yang juga mempengaruhi sistem hukum yang ada di Indonesia, yaitu Hukum Adat dan Hukum Islam, yang akhirnya mengacu kepada suatu sistem hukuman gabungan baru yang dilandaskan pada Pancasila.

\footnotetext{
${ }^{11}$ Purba, Hasim., \& Purba. Op.Cit. HIm 174

${ }^{12}$ Irwansyah. Op.Cit. HIm 177

${ }^{13}$ Purba, Hasim., \& Purba. Loc.Cit

${ }^{14}$ Irwansyah. Loc.Cit

${ }^{15}$ Nurul Qamar, Perbandingan Sistem Hukum Dan Peradilan Civil Law System Dan Common
} Law System (Makassar: Pustaka Repleksi, 2010). HIm 46 
1. SISTEM HUKUM ADAT

Sistem hukum adat merupakan salah satu sistem hukum yang cukup berpengaruh di Indonesia, bahkan di semua daerah di Asia. Contoh yang terkenal dari sistem hukum ini adalah budaya samurai / bushido di Jepang yang menyentuh semua kalangan di Jepang terutama di level pejabat pejabatnya, mereka (pejabat - pejabat Jepang) lebih memilih untuk mengundurkan diri atau bahkan melakukan harakiri untuk menyelamatkan muka dan / atau menghindarkan skandal.

Hukum adat di Indonesia sendiri berasal dari istilah " Adatrecht" yang dikemukakan Snouck Hurgronye. ${ }^{16}$ Sistem ini memiliki ciri - ciri : ${ }^{17}$
a) Sederhana
b) Tradisional
c) Religious-magis
d) Komunal

Sistem hukum adat umumnya berkembang dari peraturan yang tidak tertulis di masyarakat. Secara konstitusional, Republik Indonesia menganut prinsip keberagaman budaya sehingga dalam lambang negara Republik Indonesia digunakan semboyan Bhinneka Tunggal Ika. Prinsip ini juga dilihat secara nyata dalam ketentuan hukum positif Indonesia, antara lain ketentuan UU NO. 5 Tahun 1960 tentang Peraturan Dasar Pokok - Pokok Agraria yang menentukan bahwa hukum agraria yang berlaku atas air, bumi, dan ruang angkasa ialah Hukum Adat. ${ }^{18}$ Ajaran hukum adat tersebut dalam praktek peradilan dijadikan sebagai salah satu asas hukum nasional untuk mendukung proses pembangunan nasional. ${ }^{19}$

\section{SISTEM HUKUM NASIONAL}

Indonesia sebagai suatu negara yang berdaulat selama 75 tahun, memerlukan suatu sistem hukum tersendiri yang dapat memfasilitasi kearifan

\footnotetext{
${ }^{16}$ Purba, Hasim., \& Purba. Op.Cit Hlm 176

${ }^{17}$ Irwansyah. Op.Cit. HIm 183

18 H.P Panggabean, Praktek Pengadilan Menangani Kasus-Kasus Hukum Adat Suku-Suku Nusantara (Jakarta: Bhuana Ilmu Populer, 2020). HIm 3

${ }^{19} \mathrm{Ibid}, \mathrm{hlm} 4$
} 
lokal berdasarkan pada keragaman suku dan budaya sehingga hukum hukum adat yang ada di nusantara ini dapat diperhitungkan. Selain itu seperti yang disampaikan Teguh Prasetyo dalam jurnal ilmiahnya dan dikutip,

" Perlunya sistem hukum tersendiri di Indonesia sudah sangat urgent atau mendesak, karena masyarakat sudah tidak percaya lagi pada sistem hukum yang ada pada saat ini, terutama di bidang penegakan hukum." ${ }^{20}$

Beliau menyampaikan hal ini mengingat sistem hukum yang ada di Indonesia masih mengacu kepada civil law sisa peninggalan zaman penjajahan Belanda. Bahkan lebih jauh beliau menyampaikan," Pembangunan sistem hukum yang berlandaskan kepada Pancasila harus diarahkan untuk menampung dan mendukung kebutuhan - kebutuhan hukum sesuai dengan perkembangan dan kemajuan pembangunan yang terjadi di bidang lain, sehingga sistem hukum Pancasila mampu untuk menciptakan ketertiban dan kepastian hukum yang bertujuan untuk meningkatkan persatuan dan kesatuan bangsa dan negara. ${ }^{21}$

Secara tidak langsung Teguh Prasetyo dalam jurnalnya telah menyebutkan suatu sistem hukum baru, yaitu sistem hukum Pancasila. Kemudian pada alinea ke - 4 Pembukaan UUD 1945 - yang tidak akan diubah apa pun alasannya - tercantum secara eksplisit Pancasila. Pancasila yang juga dikatakan sebagai sumber dari segala sumber hukum negara, sesuai dengan Pembukaan UUD 1945 yang menjadikannya sebagai dasar, ideologi, dan filsafat negara (Pasal 2 UU No. 12 Tahun 2011 tentang Pembentukan Perundang - Undangan). Berdasarkan itu Pancasila adalah "ideologi hukum" nasional yang masih dipakai. ${ }^{22}$ Oleh karena itu Pancasila sebagai ideologi dengan demikian adalah legitimasi bagi hukum nasional Indonesia. ${ }^{23}$

Pancasila melalui kutipan pernyataan di atas, telah menjadi landasan dasar suatu sistem hukum yang dapat memfasilitasi hukum adat, civil law

20 Teguh Prasetyo, 'Membangun Sistem Hukum Pancasila Yang Merdeka Dari Korupsi Dan Menjunjung HAM', Jurnal Repleksi Hukum, Volume 8.Nomor 1 (2014),HIm 24.

${ }^{21}$ Ibid, HIm 26

22 Hyronimus Rhithi, Cita Hukum Dan Postmodern Kajian Gagasan Ekologis Pancasila (Yogyakarta: Genta Publishing, 2020). HIm 9

${ }^{23}$ Ibid, hlm 9 
sisa peninggalan penjajahan Belanda, dan hukum Islam, sebagaimana timbulnya Undang - Undang No. 10 Tahun 1998 tentang Perbankan Syariah, Undang - Undang No. 38 Tahun 1999 tentang Pengelolaan Zakat, Undang Undang No. 17 Tahun 1999 tentang Penyelenggaran Ibadah Haji.

Saat ini bahkan sistem hukum common law pun telah difasilitasi oleh sistem hukum Indonesia, seperti yang diungkapkan oleh Dhanisworo K. Harjono dalam jurnalnya dan dikutip,"Masuknya sistem hukum asing dalam bidang ekonomi ke dalam sistem hukum Indonesia tidaklah dapat dihindari dan kita tidak dapat menutup mata terhadap masuknya unsur atau lembaga yang tunduk pada pranata hukum yang berbeda. Bahkan kebijakan dalam bidang EKUIN pada umumnya mengembil ketentuan dari sistem hukum Common Law, yang kadang kala tidak cocok diterapkan di negara kita yang menganut sistem Civil Law terutama yang menyangkut prosedur yang dibentuk dari sejarah, budaya, tradisi hukum masing masing negara yang berbeda. ${ }^{124}$

Sehingga terlepas Pancasila belum disebut sebagai suatu sistem hukum nasional secara luas, namun kenyataannya adalah, kemajemukan sistem hukum yang dianut di Indonesia, mengarah kepada suatu sistem hukum nasional baru yang dilandaskan pada Pancasila. Hal ini sesuai dengan yang diungkapkan oleh Achmad Irwan Hamzani, Mukhidin, Havis Aravik dalan jurnal ilmiahnya dan dikutip, "Setelah amandemen UUD RI 1945, konsep negara hukum di Indonesia bukan lagi Rechtsstaat atau Rule Of Law, melainkan Negara Hukum Indonesia yang seharusnya berwujud dalam bentuk hukum Pancasila." 25

${ }^{24}$ Dhaniswara K. Harjono, 'Pengaruh Sistem Hukum Common Law Terhadap Hukum Investasi Dan Pembiayaan Di Indonesia', Lex Jurnalica, Volume 6.Nomor 3 (2009), Hlm 185.

${ }^{25}$ Havis. Hamzani, Achmad Irwan., Mukhidin, \& Aravik, 'Cita Hukum Pancasila Di Antara Pluralitas Hukum Nasional, Program Doktor Ilmu Hukum Universitas Muhammadiyah Surakarta', in Prosiding Seminar Nasional Hukum Transdental 2019 (Surakarta, 2019), HIm 227 <https://publikasiilmiah.ums.ac.id/handle/11617/11278?show=full > [accessed 25 December 2020]. 


\section{PENUTUP}

Sebagai kesimpulan perbandingan antara civil law, common law, sistem hukum adat, dan sistem hukum nasional, Indonesia walaupun awalnya memulai dengan sistem hukum civil law namun dalam perjalanan waktunya telah berkembang menjadi suatu sistem hukum yang majemuk atau gabungan, bahkan dapat menghasilkan suatu sistem hukum nasional baru.

Kemajemukan sistem hukum yang kemudian difasilitasi oleh suatu sistem hukum nasional yang berlandaskan Pancasila merupakan suatu yang unik, karena tidak ada negara manapun di dunia yang memiliki suatu ideologi yang dapat memfasilitasi kehidupan berbangsa dan bernegara serta sekaligus memberikan kepastian hukum dilandaskan pada campuran dan / atau gabungan dari 3 sistem hukum besar dunia serta menambahkan sistem hukum keagamaan di dalamnya, tanpa menunjukkan citra diri sebagai negara agama walaupun populasinya mencirikan pada 1 agama tertentu.

Hal ini tentu saja mendatangkan sanjungan dan pujian dari berbagai negara seperti yang disampaikan oleh Kompas.com tertanggal 8 Oktober 2020 dalam artikelnya " Membumikan dan mengglobalkan ideologi Pancasila ". ${ }^{26}$ Oleh karena itu sudah saatnya Indonesia berbangga dengan sistem hukum nasional yang dimilikinya tanpa terus melupakan kewajiban untuk terus mengembangkannya sampai mencapai titik kematangan seperti yang disampaikan Friedrich Carl Von Savigny dalam aliran sejarahnya.

\section{DAFTAR PUSTAKA}

\section{BUKU-BUKU}

Irwansyah, 2020. Kajian ilmu hukum. Yogyakarta : Mirra Buana Media.

Panggabean, H.P., 2020. Praktik peradilan menangani kasus kasus hukum adat suku suku nusantara. Jakarta : Bhuana Ilmu Populer

\footnotetext{
${ }^{26}$ Hasannuddin Wahid, 'Membumikan Dan Mengglobalkan Ideology Pancasila.', Kompas.Com, $2020<$ https://www.kompas.com/tren/read/2020/10/08/135948465/membumikan-dan-
mengglobalkan-ideologi-pancasila?page=all> [accessed 25 December 2020].
} 
Purba, Hasim., \& Purba, Muhammad Hadyan Yunhas., 2019. Dasar dasar pengetahuan ilmu hukum. Jakarta : Sinar Grafika.

Qamar, Nurul., 2010. Perbandingan sistem hukum dan peradilan civil law system dan common law system, Makassar : Pustaka Refleksi.

Rahardjo, Satjipto., 2006. Ilmu hukum. Bandung : Citra Aditya Bakti.

Rahayu, Sri., 2015, Hak tertuduh dalam peradilan pidana berdasarkan adversary system, Jurnal Inovatif Volume VIII Nomor I, Januari 2015.

Rhiti, Hyronimus., 2020. Cita hukum dan postmodern kajian gagasan ekologis Pancasila. Yogyakarta : Genta Publishing

\section{JURNAL/ ARTIKEL}

Harjono, Dhaniswara K., 2009, Pengaruh Sistem Hukum Common Law terhadap Hukum Investasi dan Pembiayaan di Indonesia, Lex jurnalica Vol. 6 No. 3, Agustus 2009

Prasetyo, Teguh., 2013. Membangun sistem hukum Pancasilayang merdeka dari korupsi dan menjunjung HAM, Jurnal refleksi hukum Vol 8 No. 1, April 2014

\section{INTERNET/WEBSITE}

Hamzani, Achmad Irwan., Mukhidin, \& Aravik, Havis., 2019, Cita hukum Pancasila di antara pluralitas hukum nasional, Prosiding Seminar Nasional Hukum Transdental 2019, Program Doktor Ilmu Hukum Universitas Muhammadiyah Surakarta (https://publikasiilmiah.ums.ac.id/handle/11617/11278?show=full)

Wahid, Hasannuddin., 8 October 2020. Membumikan dan mengglobalkan ideology Pancasila. Kompas.com (https://www.kompas.com/tren/read/2020/10/08/135948465/membumikandan-mengglobalkan-ideologi-pancasila?page=all) 